\title{
Crowing sound and inbreeding coefficient analysis of Pelung chicken (Gallus gallus domesticus)
}

\author{
BUDI S. DARYONO ${ }^{1, \bullet}$, MIFTAHUL MUSHLIH ${ }^{2}$, AYUDHA BAHANA ILHAM PERDAMAIAN ${ }^{1}$ \\ ${ }^{1}$ Laboratory of Genetics and Breeding, Faculty of Biology, Universitas Gadjah Mada. Jl. Teknika Selatan, Sleman 55281, Yogyakarta, Indonesia. \\ Tel.: +62-274-580839, Fax.: +62-274-6492355, •email: bs_daryono@mail.ugm.ac.id \\ ${ }^{2}$ Laboratory of Molecular Biology, Faculty of Health Science, Universitas Muhammadiyah Sidoarjo. Jl. Raya Lebo No. 4, Rame Pilang, Wonoayu, \\ Sidoarjo 61261, East Java, Indonesia
}

Manuscript received: 15 November 2020. Revision accepted: 2 April 2021.

\begin{abstract}
Daryono BS, Mushlih M, Perdamaian ABI. 2021. Crowing sound and inbreeding coefficient analysis of Pelung chicken (Gallus gallus domesticus). Biodiversitas 22: 2451-2457. Pelung is one of the crowing-typed chickens from Indonesia. The bioacoustics characters of Indonesian crowing-typed chicken especially Pelung chicken were less documented. This study aimed to characterize crowing sound and to study the inbreeding coefficient of the Pelung chicken. In this study, crowing voice of 77 male Pelung chicken was recorded. Bioacoustics analyses of crowing voice were done using Adobe Audition CS5.5 and PRAAT 5.3.66 software. The results showed that chicken crowing consisted of front sound (first syllable), middle sound (second syllable) and end sound (third syllable). Each section of Pelung crowing had specific characteristics compared to other chicken breeds and varied among champions and nonchampions. Champion chicken had slowed and clear first and second syllable, sound energy was lower in first syllable then decrease at second syllable and has bitu gantung third syllable. Crowing duration and fundamental frequency (F0) of champion and non-champion were not statically different. The inbreeding coefficient reached 0.53 in several Pelung champions. Based on the research findings, bioacoustics software was applicable to assist the chicken show.
\end{abstract}

Keywords: Bioacoustics, crowing characteristic, Indonesian crowing-typed chicken, Pelung chicken

\section{INTRODUCTION}

In Indonesia, 28 local chicken breeds had identified and documented. Each breed has a morphological identifier and different potentials (Ulfah et al. 2016). Among Indonesian chicken breeds, four breeds have the ability in producing a distinctive crowing sound so-called a singer chicken. Singer chicken can produce a melodious sound, as well as rhythm but varying in character (Ulfah et al. 2017). These four breeds categorized as singer chicken were Kokok balenggek chicken from West Sumatra, Bekisar chicken from East Java, Gaga chicken from southern Sulawesi, and Pelung chicken from Cianjur District, West Java Province (Daryono et al. 2020). Three of them (Gaga, Kokok balenggek, Pelung, respectively) have been patented as genetic treasurer of Indonesia in 2011 by Indonesian Ministry of Agriculture. In this research, the authors attempt to describe these four chicken breeds.

In this research, the authors deeply concentrate on Pelung chicken. At glance, Pelung chicken has a large body compared with the other local Indonesian chickens. Adult females have an average weight of 4,500 gr while the male has 5.400 gr (Asmara1 et al. 2020; Asmara2 et al. 2020). The other local chicken breed weight was just approximately 1,500 to 1,800 gr for adult males and 1,000 to1,400 gr for females. However, for Pelung chicken enthusiasts, Pelung chicken usually maintained if it has a good voice or has potential for competition, while Pelung chicken with regular voice is usually sold to a market or used as a source of food. Pelung chicken mating usually well documented so the pedigree was clear. Chicken with the same predecessor grouped as the same clan (trah) which determines the chicken price. For example, trah Lembayung and trah Gerandong which had approximately eight times winning records were expensive than the others. Closely related mating makes the inbreeding coefficient arguably high.

Pelung has a distinctive crowing voice (called: melung) with a characteristic sound that long, undulating, loud and rhythmic. For beginner readers, the sound of Pelung chicken crowing was like common chicken but much longer with a prolonged end. Pelung chicken singing competition often held by several agencies. One of them by the district government held regularly to preserve the existence of Pelung chicken. The winner of each chicken show was determined by a group of judges which consisted of three to four persons with one leader. Subjectivity might occur during the examination. On this occasion, the authors were compiling the chicken voice recordings from different champions to make a standardization.

Vocalization was important character for identification which had been studied in Toad (Wang et al. 2019) and Liocichla (Kong et al. 2020). This research aimed to study the bioacoustics character and study the inbreeding coefficient of Pelung chicken. 


\section{MATERIALS AND METHODS}

The study was done in 2018 in Cianjur, West Java, Indonesia as the central development of Pelung chicken. 77 male Pelung chicken were used in this research.

\section{Bioacoustics analysis}

Pelung chicken crowing sound data retrieval by purpose ve sampling method using a voice recorder, by using a set of digital voice recording (SONY ICD-UX533F). The crowing of each chicken was done by 1 to 5 repetitions (minimum) or to obtain an optimal sound. Form these repetitions, the crowing voice used in this research was based on the opinions of the expert. The crowing voice used in this research was the best that can be produced by the sample. The distance of recording approximately 500 $\mathrm{cm}$ from the object. Recorded sound stored in the ".wav" form, then analyzed with Adobe Audition CS5.5 and PRAAT 5.3.66 software. The parameters used in this study are presented in Table 1. Voice was transformed into a waveform and spectrogram to show the voice pattern. The waveform can be a representation of the voice graph. Formant is a spectrum of peak waves to another peak wave. To at least three formants (F1, F2, F3) (Jenny 2013). Statistical analysis was done by the T-independent test and ANOVA.

\section{Champion sound analysis}

In this research, the authors attempt to analyze the champion sound characters. Pelung chicken divided into two bioacoustics analyses, chicken with winning record were grouped as champion while others grouped as nonchampion.

\section{Inbreeding coefficient analysis}

Pedigree construction was done by interview at least two reliable breeders. inbreeding coefficient calculated using the standard formula (Frankham et al. 2002).

$$
F=\sum\left(\frac{1}{2}\right)^{n}
$$

Where; F was the Inbreeding Coefficient (IC) and $\mathrm{n}$ was the number of lines of mating.

\section{RESULTS AND DISCUSSION}

\section{Chicken crowing bioacoustics}

Indonesia has three natural chicken breeds (Kokok balenggek, Gaga, Pelung, respectively) and one hybrid chicken breed (Bekisar) which especially breed to sing (Rusfidra and Arlina 2014). In this research, we managed to describe them. The different chicken breeds might produce various sound characters in each part. Dwarf chicken (Ayam Kate) and Crested chicken Ayam Mahkota) have the same crowing voice parts compared to Pelung chicken but different in duration (Figure 1).

Pelung chicken crowing duration reached 8.435 \pm 1.647 seconds while Crested and Dwarf chicken only $1.975 \pm$ 0.2252 seconds and $1.772 \pm 0.2698$ seconds. Pelung chicken crowing duration more than four times longer than a dwarf and a crested chicken.

Table 1. Pelung chicken crowing sound parameters

\begin{tabular}{ll}
\hline Parameter & Definition \\
\hline Crowing duration & Entire crowing vocalization \\
F0 syllable (Pitch) & Average F0 at first syllable \\
Min. F0 syllable & F0 (pitch)* minimum at first syllable \\
Max. F0 syllable & F0 (pitch)* maximum at first syllable \\
First syllable duration & Entire first syllable \\
Element duration & First syllable element duration \\
Silent interval & Silent duration between element and first syllable \\
Second syllable duration & Entire second syllable vocalization \\
Third syllable duration & Entire third syllable vocalization \\
F0 mean & The average of F0 (pitch) at entire crowing vocalization \\
F0 min & F0 (pitch) minimal at entire crowing vocalization \\
F0 max & F0 (pitch) maximal at entire crowing vocalization \\
F0 second wave & The average of F0 (Pitch) at second syllable \\
F1 mean & The average of Formant -1 at entire crowing vocalization \\
F1 second syllable & The average of Formant -1 at second syllable \\
F2 mean & The average of Formant -2 at entire crowing vocalization \\
F2 second syllable & The average of Formant -2 at second syllable \\
F3 mean & The average of Formant -3 at entire crowing vocalization \\
F3 second syllable & The average of Formant -3 at second syllable \\
The amplitude of element & Amplitude/energy element at first syllable \\
The amplitude of first syllable & Amplitude/energy at first wave/syllable \\
The amplitude of second syllable & Amplitude/energy at second wave/syllable \\
The amplitude of third syllable & Amplitude/energy at third wave/syllable \\
\hline
\end{tabular}


Crowing sound consists of $1.104 \pm 0.210$ seconds first syllable, $5.532 \pm 1.274$ seconds second syllable, and 1.858 \pm 0.969 third syllable. The first syllable (first wave) is the sound that started the sequence of crow. The first element consists of one element and first syllable which joined in the beginning of crowing sound. Between element and syllable separated with silent interval. At the beginning of Pelung chicken crow, the element is a short wave bite that has a length of $0.1973 \pm 0.059$ sec. Element and early sound syllables separated by a pause of about $0.1213 \pm$ 0.038 seconds.

Based on the analysis, the first syllable has an F0 (fundamental frequency) around $243.875 \pm 64.260 \mathrm{~Hz}$, the minimum F0 $188.43 \pm 66.119 \mathrm{~Hz}$, and a maximum F0 $295.37 \pm 81.972 \mathrm{~Hz}$. The crowing style followed a pattern similar to syllable earlier, namely forming sound " $k u-k u$ " and then followed down the volume rises with the style called initial syllable. First syllable length $0.7924 \pm 0.20$ seconds. The length of the initial syllable around $1.1128 \pm$ 0.218 seconds.

In terms of amplitude, significant difference was noticed among the syllables. The average of energy produced by Pelung chicken is $83.237 \pm 1.780 \mathrm{~dB}$. Pelung chicken will emit a loud sound at the beginning syllable that the syllable "ku" (element component). The results showed that " $k u$ " voice has $84.849 \pm 1.758 \mathrm{~dB}$ amplitude then decreases to $83.648 \pm 1.061 \mathrm{~dB}$ when reaching the initial syllable early after the silent syllable. When it reaches the middle syllable, amplitude decreased again to $83.174 \pm 0.754 \mathrm{~dB}$. However, the decrease was significantly different at $\mathrm{P}>0.01$. off all observed Pelung crowing, the Standard deviation (SD) of the amplitude of the middle voice has the lowest value compared to other voice parts, this means that the sound is constant in this section. The second syllable was the beautiful part of the Pelung crowing.

In the end, syllable decreased to $81279 \pm 1,152 \mathrm{~dB}$. Sound energy at the end tends to have higher than syllable beginning and middle, but not higher when compared with the element at the first syllable. The Standard deviation value demonstrated a high-end control syllable was very different in individuals.

\section{The bioacoustics of the Pelung champion}

To analyze the champion characters, the authors investigate the crowing sound structure of 1st winner (champion) from several chicken shows. The limitation of this study was high variability of crowing sound (Figure 2). In different city, most of the chicken show contestant and champion was different. The subjectivity of judgment might occur. Five components were used to select a champion consisted of first syllable, second syllable, third syllable, rhythm, and harmony.

Based on voice visualization, each champion produces a similar crowing pattern. The first syllable must be slow rhythmic and clearly heard. "Ku-ku" and followed by "ellu" sound must be harmonic. The second syllable must be slow, "ke-ke...ellu.." then form an increasing sound (bitu gantung) along with "ell" sound. the L sound at bitu should be clearly heard at "elllLLLUuuu". Decrease F0 but increase the amplitude. However, the type of bitu will be described in another paper (Daryono et al. 2020). Based on our analysis, the crowing duration does not determine the quality of crowing. Crowing duration of champion and non-champion were not statically different.

The comparison of crowing energy between champion (having win record) to non-champion attempts to analyze the sound hardness (Figure 3). In terms of sound energy, in this occasion, the authors use "kekelur" typed crowing for example as champion and "kukulir" typed crowing for example as non-champion. "Kululir" was a very ordinary Pelung crowing type, and always not selected to follow a chicken show.

The champion (kekelur) produced lower sound energy than the common Pelung chicken (kukulir) at the first syllable's element. Then sound energy was noticed decreased at second syllable in both groups, this downstream was significant at the champion but not at common Pelung. At the third syllable, the champion produces lower sound energy than the common Pelung. At the third syllable, the ability to control the sound energy to produce long and decreasing crowing was the champion criteria.

Fundamental frequency (F0) and formant are important factors in bioacoustics (Figure 4). The result of the calculation cannot be used before transformed into In or $\log 10$ function (Flynn and Foulkes 2011). Based on our analysis, the fundamental frequency was not different between champion and non-champion $(p>0.01)$. Whereas among champions in Semarang chicken show, the fundamental frequency was not uniform.

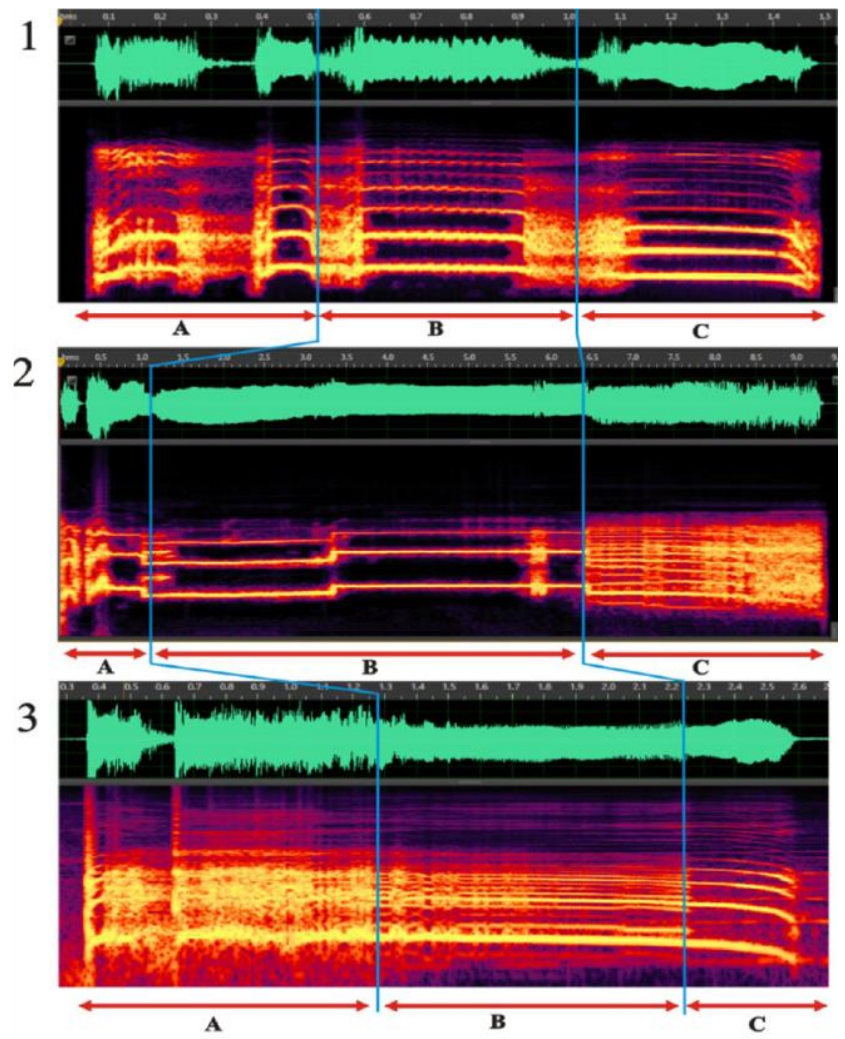

Figure 1. The comparison of first syllable (A), second syllable (B), and end syllable (C) divided by vertical blue lines crowing voice parts duration of Dwarf chicken (1), Pelung (2), and Crested chicken (3) 
Based on our visualization, F0 were highly polymorphic. F0 cannot used as a bioacoustics marker. Contrary, the value of Formant 2 (F2), F2-F1, F3, F5 were statistically different at $\mathrm{P}<0.05$ while pitch (F0), F1, F3-F2, $\mathrm{F} 4+\mathrm{F} 2$, and F4 at $\mathrm{P}<0.01$. F1, F2, F3, F4, total formant and F4+F1 at vowel "i" and " $\mathrm{u}$ " used in this research to estimate the difference between champion crowing and usual crowing voice. The F1 and F2 of "kukulir" and "kekelur" were different positions in the sound sequence (Figure 5).

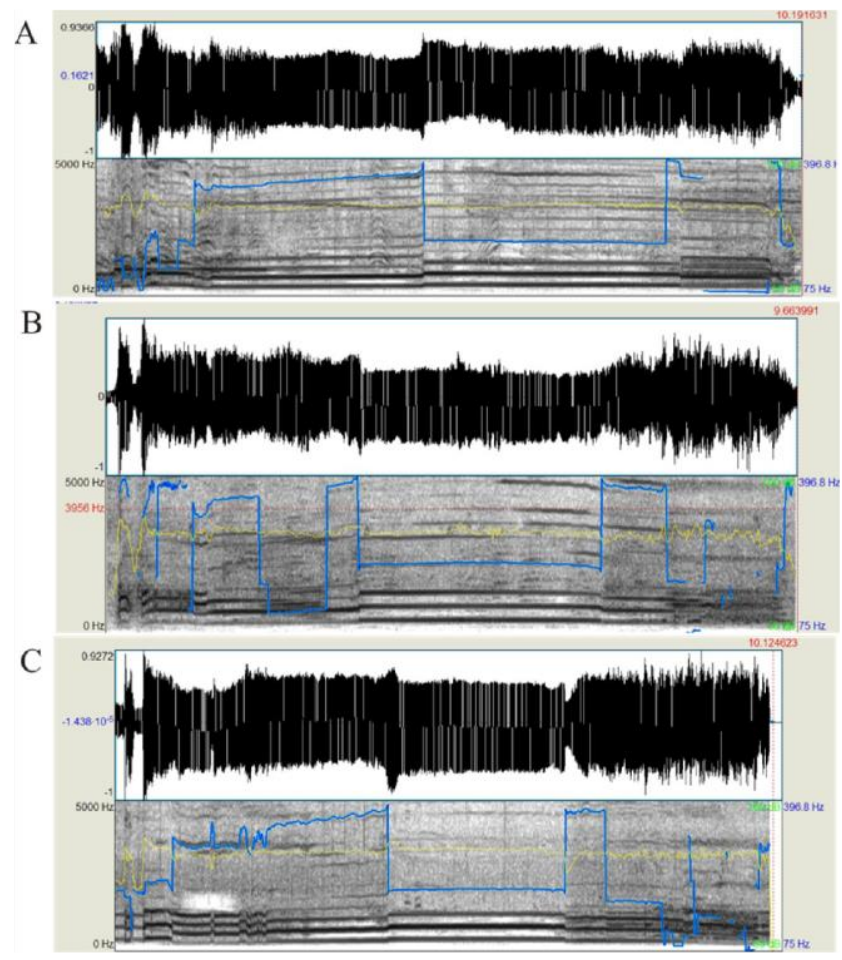

Figure 2. The crowing bioacoustics visualization of 1st winner Pelung chicken in Jakarta and Bandung chicken show (A), Surabaya chicken show (B) and Semarang chicken show (C). Blue line indicated the bitu (intonation dynamic) sequence.

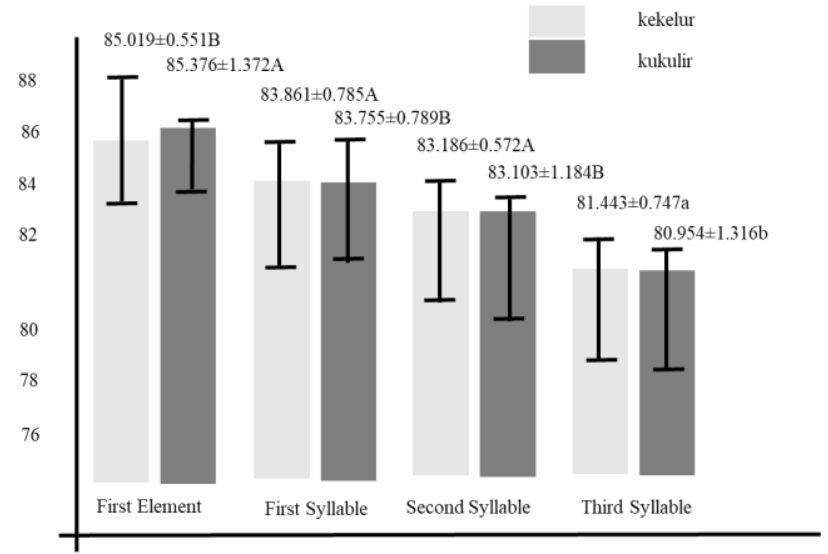

Figure 3. Energy (dB) comparison of 1 st winner chicken crowing (blue box) to typical Pelung crowing voice (red box). Superscript $\mathrm{AB}$ and $\mathrm{ab}$ indicate statistical difference at $>5 \%$ and $>1 \%$.

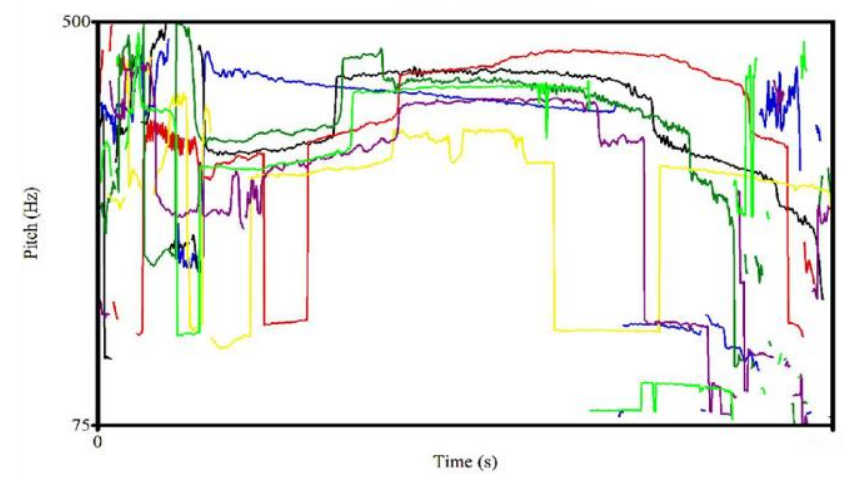

Figure 4. The comparison of the fundamental frequency (F0) of 1st winner (dark blue line) at Semarang chicken show compared to 1st winner (violet line) at Jakarta and Bandung chicken show, runner up (yellow), 10th winner (green), 17th position (red), qualified (light blue and black).

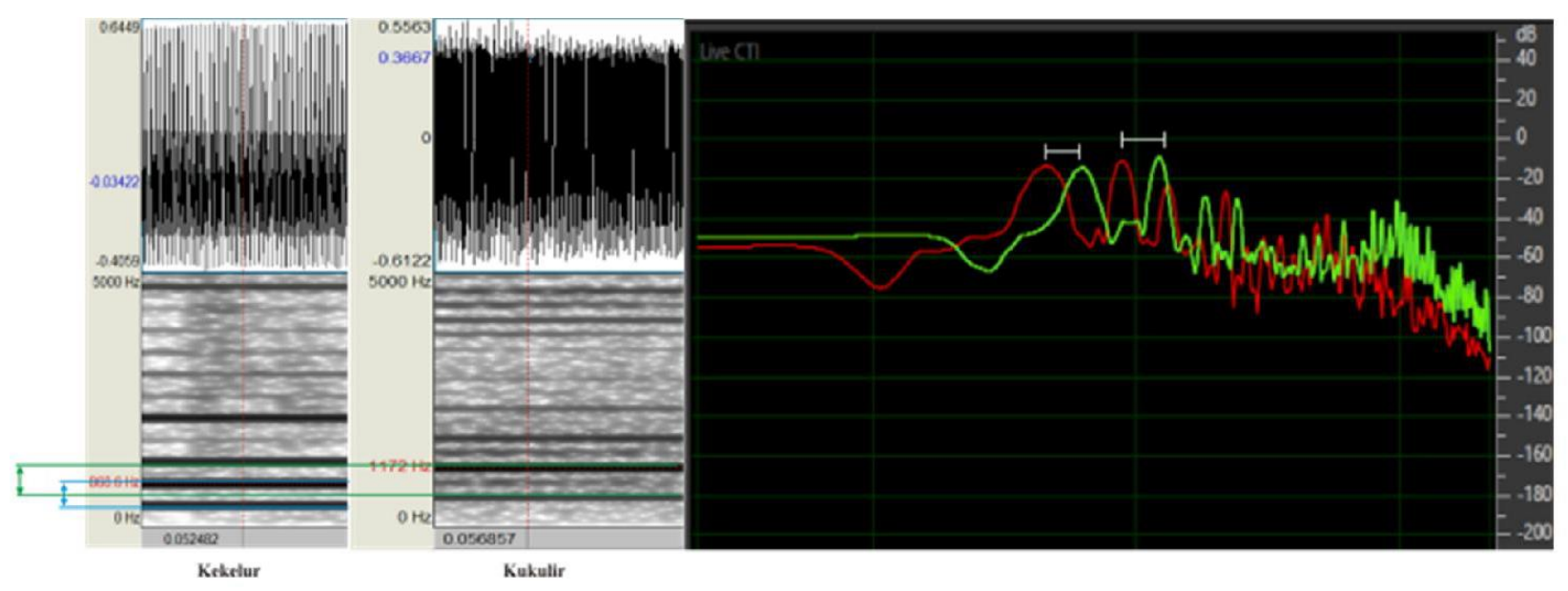

Figure 5. The visualization of "kekelur" and "kukulir" typed sound at Formant 1 (F1) and formant 2 (F2) position. Green box and blue box indicate the formant frequency difference (left panel). The sound sequence of "kekelur" (red line) and "kukulir" (green line) and white dash indicate the Formant 1 (F1) and Formant 2 (F2) position (right panel) 
The inbreeding coefficient of champion Pelung chicken

Based on our calculation, the Inbreeding Coefficient (IC) reached 0.53 at one champion named Khayangan. However, Khayangan brothers were not exhibited excellent crowing sound. Although high IC value was bad, but no physical deterioration was commonly noticed. For example, there was no statistical difference between champion and non-champion body weight. When the authors attempt to outbreed Pelung to broiler into the first Backcrossed $\left(\mathrm{BC}_{1}\right)$ population, all siblings were nonsinger. Chicken enthusiasts remember the pedigree of Pelung chicken. In the beginning, champion Pelung chicken named Rengket was descendent of Si Kaget which also had first place record. Rengket mating to female which had bloodline was produced champion chicken named Lembayung. Lembayung was the predecessor of many champions including Khayangan (Figure 6).

Lembayung mating to female named Rengge which not had bloodline was produced champion chicken named Lodaya. Kencana and Kemuning, Lodaya's offspring also had champion record. Having big name, Lembayung descendent was mated to other bloodlines, i.e. Grandong, Simega and Sidolar (pers. comm. Agus Abdurrahman). Sibling mating was regularly practiced until produce Khayangan. From many Khayangan offspring, only Samhiyang (not showed in Figure 6.) had champion criteria. Samhiyang in the learning phase (juvenile age) ever participating in chicken contest and even selected to the grand final.

\section{Discussions}

\section{Chicken crowing bioacoustics}

Indonesia has three natural chicken breeds (Kokok balenggek, Gaga, Pelung, respectively) and one hybrid chicken breed (Bekisar) which especially breed to sing (Rusfidra and Arlina 2014). In this research, we managed to describe them.

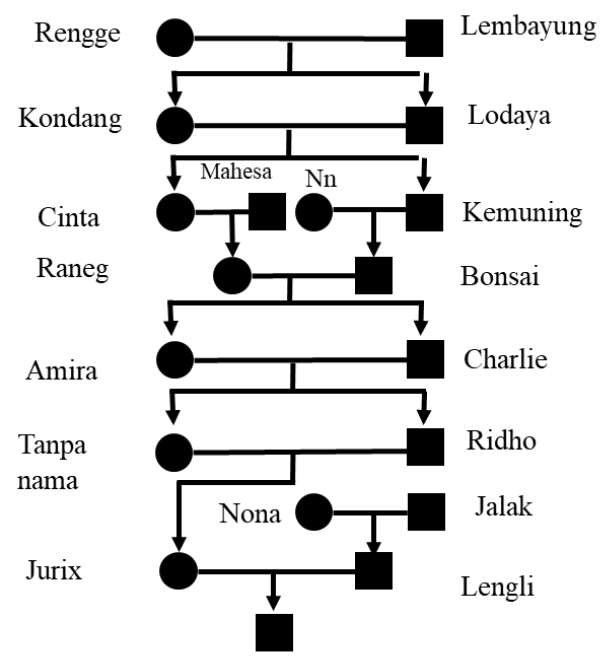

Khayangan

Figure 6. The detailed Pelung chicken pedigree shows individual Pelung names and mating scheme
Bekisar chicken was famous in Madura Island and the eastern part of Java Island. This hybrid chicken originated from the mating of the female domestic chicken (Gallus gallus domesticus) which mostly black-feathered kampung chicken breed with male green junglefowl (Gallus varius) (Ulfah et al. 2017). Bekicem (Bekisar cemani) was all black-colored Bekisar produced by crossing female cemani chicken breeds (fibromelanosis phenotype) with male green junglefowl. Although had low fertility, crossing male Bekisar to female domestic chicken able to produce the first Backcrossed line $\left(\mathrm{BC}_{1}\right)$ called Bekikuk. This male $\mathrm{BC}_{1}$ chicken has a similar appearance and crowing sound to male Bekisar.

Kokok balenggek chicken breed was originated from the Western part of Sumatra Island. Among singer-typed chicken in Indonesia, this chicken has the highest number of syllables which reached 24. Typical of this breed has a 5.07 syllable each crowing. Crowing consisted of front sound, middle sound, and end sound. The uniqueness of these breeds laid on their end voice. Kokok balenggek chicken crowing sound has a frequency of around 8.08 times/10 minutes. The crowing duration approximately 2.03 to 4.43 seconds.

The last list of the crowing typed chicken breed, Gaga chicken, is crowing type chicken that originated from the south part of Sulawesi Island (Zulistiana and Abinawantoa 2018). Gaga chicken has a crowing voice reminiscent of human laughing voice so often called as laughing chicken (Ayam Ketawa) (Abinawanto and Effendi 2017) Gaga chicken crowing voice consisted of three main parts, front voice with high intonation, middle voice laughing like a human, and sort end voice. The ending voice is the uniqueness and determines the quality and price of Gaga chicken (Bugiwati and Ashari 2013). Crowing duration around $3.68 \pm 1.08$ seconds.

Gaga chicken can be divided into two types based on the crowing rhythm and the amount of syllables (Effendi and Abinawanto 2016, Abinawanto and Effendi 2018). First, dangdut (fast rhythm typed) and common (slow rhythm typed). Based on the amount of syllables, dangdut can be divided again into two types, long dangdut, and short dangdut. Long dangdut type crowing duration reaches 30.8 seconds whereas short dangdut only 4.2 seconds while the common (slow type) around 7 seconds. The syllable recorded from long dangdut was 143 while short dangdut was only 21 , whereas the common-typed gaga chicken was only 8. Most various parts of Kokok balenggek, Gaga, and Pelung chicken crowing voice occurred in the middle voice.

Pelung chicken was originated from Cianjur, West Java province (Asmara et al. 2020). The different chicken breeds might produce various sound characters in each part. Dwarf chicken (Ayam Kate) and Crested chicken (Ayam Mahkota) have the same crowing voice parts compared to Pelung chicken but different in duration (Figure 1).

\section{The bioacoustics of the Pelung champion}

Based on voice visualization, each champion produces a similar crowing pattern. Crowing duration of champion and non-champion were not statically different. The 
comparison of crowing energy between champion (having win record) to non-champion attempts to analyze the sound hardness (Figure 3 ). the ability to control the sound energy to produce long and decreasing crowing was the champion criteria.

Fundamental frequency (F0) and formant are important factors in bioacoustics (Figure 4). The result of the calculation cannot be used before transformed into In or $\log 10$ function (Flynn and Foulkes 2011). Based on our analysis, the fundamental frequency was not different between champion and non-champion $(p>0.01)$. Whereas among champions in Semarang chicken show, the fundamental frequency was not uniform.

\section{The inbreeding coefficient of champion Pelung chicken}

The folklore about Pelung chicken origin believed by people, today Pelung chicken breed was derived from a single male ancestor. The story said that the very first Pelung chicken breed was male chick hatched from common local chicken (Ayam Kampung). This chick had bigger body appearance and late covered by feathers which when adult produces distinctive crowing sounds. In 1850s, Pelung chicken breed begins famous.

This study shows the breeding scheme of the making of satisfying Pelung chicken. As described earlier, clan (trah) and pedigree was determining the Pelung chicken price. Believed by breeder, a clan with winning record prominent for Pelung chicken breeding. Contrary, Kokok balenggek breeder not precisely made pedigree for the breeding scheme. Usually, breeder keeps their chicken free-range. That made the inbreeding coefficient remain low. (Rusfidra et al. 2014, Rusfidra et al. 2015).

Based on our calculation, the Inbreeding Coefficient (IC) reached 0.88 at one champion named Khayangan. However, Khayangan brothers were not exhibited excellent crowing sound. Although high IC value was bad, but no physical deterioration was commonly noticed. For example, there was no statistical difference between champion and non-champion body weight. Many Pelung chicken breeders use non-commercial produced feed which mainly comprised of paddy bran to minimize the detrimental effect of feed additives. This decision has consisted of other reports that evaluated the impact of chicken commercial feed on animal and human health (Ahmad et al. 2020).

Winning a chicken show would raise his price as well as his progeny. Champion male mating with a female (had closest as possible bloodline with the champion male) to producing chicken for highly competing in the chicken show. Chick was intensively reared for participating in chicken show.

When the authors attempt to outbreed Pelung to broiler into the first Backcrossed $\left(\mathrm{BC}_{1}\right)$ population, all siblings were non-singer (Utama et al. 2018). The results indicate the recessive autosomal as the inheritance mode of longcrowing sound traits. However, this theory was not linier to other singer chicken breeds. Gaga and Kokok balenggek chicken crowing ability were believed to be acquired by learning (genetics imprinting) (Bugiwati and Asyari 2013; Rusfidra 2007).
Each section of Pelung crowing has specific bioacoustics characters and vary among champions and non-champions. The inbreeding coefficient reached 0.88 in several Pelung champions. Bioacoustics software was applicable to assist the chicken show. Amplitude was different among Pelung chicken. Supported by outbreeding data, the authors propose multiple gene works responsible for Pelung crowing trait.

Inbreeding Coefficient (IC) and bioacoustics do not have direct correlation. However, Inbreeding mating in Pelung farm was carried out and maintained through generation to accumulate and preserve the ample genes responsible for crowing. This led to higher IC at Pelung champion clan which also increase the possibility to had deleterious traits.

\section{ACKNOWLEDGEMENTS}

The authors want to acknowledge Universitas Gadjah Mada for providing the applied technology research fund (020/ST/KP4/DIPA/UGM/2013) and the language editing service. The University Farm (Pusat Inovasi Agroteknologi Terpadu; PIAT) for providing the Academic, Business, Community, and Government (ABCG) network development research fund (No. 031/ST/KP4/DIPA/UGM/ 2013). This study was financially supported by Applied Research grant (Penelitian Terapan/PT No. 1997/UN1.DITLIT/DIT-LIT/PT/2020) of Ministry of Research Technology and Higher Education of Indonesia

\section{REFERENCES}

Abinawanto A, Effendi PS. 2018. The bioacoustics analysis and the morphometrics study of the Gaga's chicken (ayam ketawa) from Pinrang and Kebayoran Lama. AIP Conf Proc 2023: 020137. DOI: $10.1063 / 1.5064134$

Ahmad S, Ahmed L, Haider S, Batool Z, Liaquat L, Ahmed F, et al. 2020. Effects of feed additives on chicken growth and their residues in meat instigating deleterious consequences on the liver health of consumers - a prospective human study. Pakistan J Zool 52 (3): 909-916. DOI: 10.17582/journal.pjz/20181121161104.

Asmara IY, Garnida D, Partasasmita R. 2020. Crowing characteristics of Pelung chickens at different age and body weights. Biodiversitas 21 (9): 4339-4344. DOI: 10.13057/biodiv/d210953.

Asmara IY, Garnida D, Partasasmita R. 2020. Duration and volume of crowing of Pelung chickens of West Java, Indonesia. Biodiversitas 21 (2): 748-752. DOI: $10.13057 /$ biodiv/d210242

Boersma P, Weenink D. 2005. Beginners guide to Praat. https://person2.sol.lu.se/SidneyWood/praate/frames.html [14 August 2020]

Bugiwati SRA, Ashari F. 2013. Crowing sound analysis of Gaga' chicken: local chicken from South Sulawesi Indonesia. Intl J Plant Anim Environ Sci 3 (2): 163-168.

Daryono BS, Mushlih M, Perdamaian ABI. 2020. Vocalization characters and Forkhead Box P2 (FoxP2) polymorphism in Indonesian crowingtype chicken (Gallus gallus domesticus). Iran J Appl Anim Sci 10 (1): 131-140.

Effendi PS, Abinawanto A. 2016. Biodiversity of the Gaga' chicken (Ayam Ketawa) from Sidenreng-Rappang based on the bioacoustic analysis and the morphometric study. AIP Conf Proc 1729: 020071. DOI: $10.1063 / 1.4946974$.

Flynn NEJ, Foulkes P. 2011. Comparing vowel formant normalization methods. In Lee WS, Zee E. (eds.). Proceedings of the 17th ICPhS. City University of Hong Kong, Hong Kong. 
Frankham R, Ballou JD, Briscoe DA. 2002. Introduction to Conservation Genetics. Cambridge Univesity Press, Cambridge, UK.

Jenny. 2013. The effect of Tonsillectomy using adenoidectomy to formant frequency [Thesis]. Faculty of Medicine, Gadjah Mada University, Yogyakarta. [Indonesian]

Kong C, Wu Y, Lou S, Chen B, Dowell SD, Fu Y. 2020. Individual identification based on the songs of the Emei Shan Liocichla (Liocichla omeiensis). Pakistan J Zool 52 (2): 617-624. DOI: 10.17582/journal.pjz/20170510120508.

Rusfidra S, Marajo Dt. T, Heryandi Y, Oktaveriza B. 2014. Estimation of Inbreeding Rate in Kokok balenggek Chicken (KBC) population under ex-situ conservation. Intl J Poult Sci 13: 364-367. DOI: 10.3923/ijps.2014.364.367.

Rusfidra, Arlina F. 2014. A review of "long crower chickens" as poultry genetic resources in Indonesia. Intl J Poult Sci 13: 665-669. DOI 10.3923/ijps.2014.665.669.

Rusfidra, Gusrizal M, Gusrin Y, Abbas M, Husmaini H, Arlina F, et al. 2015. Flock composition, effective population size and inbreeding rate of Kokok balenggek chicken breed under in-situ conservation. Int. J. Poult. Sci 14: 117-119 DOI: 10.3923/ijps.2015.117.119.

Rusfidra, Tumatra YY, Abbas M H, Heryandi Y, Arlina F. 2014 Characterization of number of crow and qualitative marker of Kokok balenggek song fowl inside a captive breeding farm in Solok Regency, West Sumatera Province, Indonesia. Intl J Poult Sci 13: 343-346. DOI: 10.3923/ijps.2014.343.346
Rusfidra. 2007. Bioacoustic assessment of the Belengek crown chickens "the local sing fowl" from West Sumatra. National Seminar on Animal Husbandry and Veterinary Technology, Balai Besar Penelitian Veteriner, Bogor. [Indonesian]

Ulfah M, Kawahara-Miki R, Farajalllah A, Muladno M, Dorshorst B, Martin A, Kono T. 2016. Genetic features of red and green junglefowls and relationship with Indonesian native chickens Sumatera and Kedu Hitam. BMC Genomics 17: 320. DOI: 10.1186/s12864-016-2652-z.

Ulfah M, Perwitasari D., Jakaria J., Muladno M., Farajallah A. 2017. Multiple maternal origins of Indonesian crowing chickens revealed by mitochondrial DNA analysis. Mitochondrial DNA A DNA Mapp Seq Anal 28 (2): 254-262. DOI: 10.3109/19401736.2015.1118069.

Utama IV, Perdamaian ABI, Daryono BS. 2018. Plumage uniformity, growth rate and growth hormone polymorphism in Indonesian hybrid chickens. Intl J Poult Sci 17 (10): 486-492. DOI: 10.3923/ijps.2018.486.492.

Wang T, Jia L, Zhai X, Cui J, Wang J. 2019. The vocalizations and hearing sensitivity of an explosive-breeding tropical Toad from Southern China: A Test of the Matched Filter Hypothesis. Pakistan J Zool 51 (2): 737-745. DOI: 10.17582/journal.pjz/2019.51.2.737.745.

Zulistiana T, Abinawanto A. 2018. Morphometric and bioacoustic analysis Gaga chicken (Gallus gallus domesticus) at Bangkalan, Kamal Madura. AIP Conf Proc 2023: 020142. DOI: $10.1063 / 1.5064139$ 